University of Nebraska - Lincoln

DigitalCommons@University of Nebraska - Lincoln

1976

\title{
Evaluation of Beef Cattle Range Supplements Containing Urea and Biuret
}

Ivan G. Rush

University of Nebraska, Panhandle Research and Extension Center, irush1@unl.edu

R. R. Johnson

University of Tennessee

Robert Totusek

Oklahoma State University

Follow this and additional works at: https://digitalcommons.unl.edu/panhandleresext

Part of the Agriculture Commons

Rush, Ivan G.; Johnson, R. R.; and Totusek, Robert, "Evaluation of Beef Cattle Range Supplements Containing Urea and Biuret" (1976). Panhandle Research and Extension Center. 15.

https://digitalcommons.unl.edu/panhandleresext/15

This Article is brought to you for free and open access by the Agricultural Research Division of IANR at DigitalCommons@University of Nebraska - Lincoln. It has been accepted for inclusion in Panhandle Research and Extension Center by an authorized administrator of DigitalCommons@University of Nebraska - Lincoln. 


\title{
EVALUATION OF BEEF CATTLE RANGE SUPPLEMENTS CONTAINING UREA AND BIURET ${ }^{1,2}$
}

\author{
Ivan G. Rush ${ }^{3}$, R. R. Johnson ${ }^{4}$ and Robert Totusek ${ }^{5}$ \\ Oklaboma Agricultural Experiment Station, Stillwater 74074
}

\section{SUMMARY}

Two winter trials were conducted with 304 lactating range cows on dry grass to evaluate non-protein-nitrogen (NPN) in 30\% protein supplements containing biuret (pure and feed grade), urea and extruded grain-urea. The NPN sources contributed one-half of the supplemental nitrogen with natural 15 and $30 \%$ protein supplements serving as negative and positive controls.

Winter weight loss of cows was greater $(\mathrm{P} \approx .02)$ on the negative than on the positive control in both trials. The apparent utilization of all NPN sources was low and the utilization of urea and extruded grain-urea was less than pure or feed grade biuret. Rumen biuretolytic activity was apparent within 6 days and reached and maintained a high level of activity 20 days after the initiation of feeding biuret, even with intermittent supplementation. Apparent value of NPN supplements was slightly improved with $40 \%$ dehydrated alfalfa but not with methionine-hydroxy-analogue (MHA). Palatability of supplements was lowered by urea and especially

\footnotetext{
${ }^{1}$ Journal Article 2814 of the Agricultural Experiment Station, Oklahoma State University, Stillwater.

${ }^{2}$ The authors express appreciation to R. K. Johnson and $\mathrm{J}$. V. Whiteman for assistance in statistical analysis and Bill Sharp and Ray Heldermon for care of experimental animals. Grateful acknowledgement is also expressed to Dow Chemical, Midland, Michigan, for feed grade biuret and partial financial support; $E$. I. duPont de Nemours and Company, Wilmington, Delaware, for a source of methionine-hydroxy-analogue and partial financial support; Far-Mar-Co., Inc., Hutchinson, Kansas, for a source of extruded ureagrain and partial financial support; Nipak, Pryor, Oklahoma for urea and pure biuret, and Triple " $F$ " Feeds, Des Moines, lowa for a source of extruded urea-grain.

${ }^{3}$ Presently Distriet Extension Livestock Specialist, Panhandle Experiment Station, Scottsbluff, Nebraska.

${ }^{4}$ Presently Head, Animal Science Department, University of Tennessee, Knoxville 37900.

${ }^{5}$ Department of Animal Sciences and Industry, Oklahoma State University, Stillwater $\mathbf{7 4 0 7 4 .}$
}

by MHA and extruded grain-urea.

In a third trial with yearling heifers fed prairie hay, gains were similar on natural protein and supplements containing urea or extruded grain-urea to provide one-half of the nitrogen. When the heifers were fed the same supplements but low quality winter harvested range grass, NPN utilization appeared to be low. (Key Words: Urea, Biuret, MHA, Alfalfa, Wintering Cows.)

\section{INTRODUCTION}

Urea is the most common NPN source used in range supplements. Because urea is rapidly hydrolyzed, much of the ammonia produced in excess of available energy supplied by low quality forage is lost (Bloomfield et al., 1960) and animal performance is often lower than desired.

Utilization of NPN in low quality roughage rations may possibly be increased with biuret (Johnson and Clemens, 1973) or extruded grain-urea (Helmer et al., 1970) to provide slower ammonia release. Laboratory studies indicate rumen microflora must adapt to biuret before developing biuretolytic activity (Clemens and Johnson, 1973; Gilchrist et al., 1968; Johnson and Clemens, 1973).

Apparent utilization of urea has been improved with dehydrated alfalfa (Karr et al., 1965). Milk production was improved by MHA fed to dairy cows (Griel et al., 1968) and beef cows (Varner et al., 1973) with rations of all natural protein.

The purpose of this research was to determine (1) the apparent utilization of biuret (pure and feed grade), urea and extruded grain-urea in range cattle supplements, (2) the value of MHA and a high level of dehydrated alfalfa in range cattle supplements containing high levels of biuret and urea, and (3) the rate and extent of biuret adaptation by cattle under range conditions. 


\section{EXPERIMENTAL PROCEDURE}

Trial 1. Trial 1 was conducted during the winter on the Lake Carl Blackwell Range in Central Oklahoma on dry native range grass. Predominant forages are of the tallgrass prairie type with climax species consisting of little bluestem (Andropogon scorparius), big bluestem (Andropogon gerardi), Indian grass (Sorghastrum nutans), and switch grass (Panicum virgatum). Dry range grass was abundant; prairie hay was fed only several days when ice or snow covered the grass.

A total of 140 experimental cows included 39 mature Hereford cows, 43 mature Angus cows and 58 first-calf Hereford heifers. Mature cows calved either shortly before or after the trial started while first-calf Hereford heifers calved during early fall before the experiment started. Cows were randomly assigned within breed and age to nine supplement treatments. The wintering trial was initiated December 27 and was terminated March 27, an 88-day period.

Ingredient makeup of supplements is shown in table 1. Supplements $1,2,3,4,5,6 \mathrm{~A}, 7 \mathrm{~A}, 8$ and 9 were fed in trial 1 . Supplements 1 and 2 , formulated to contain 15 and $30 \% \mathrm{CP}$, contained all natural protein and served as negative and positive controls, respectively. The remaining seven supplements were formulated to contain $30 \%$ CP (90\% DM basis), with one-half of the CP from NPN sources. All supplements were formulated to contain $1.25 \%$ phosphorus, $.5 \%$ calcium and a nitrogen:sulphur ratio of 14:1. MHA was added (supplements 6A, 7A) to provide 10 and $20 \mathrm{~g}$ per head daily before and after calving, respectively. Supplements were processed into $.98 \mathrm{~mm}(1 / 4 \mathrm{in}$.) pellets.

Cows, allowed to graze in a common pasture, were gathered to a central feeding area in the morning 6 days each week, placed in $.91 \times$ $2.44 \mathrm{~m}$ stalls and individually fed their supplement. Twenty minutes were allowed for consumption of supplements; feed refusals were recorded. Supplement offered per cow each feeding was .79 and $1.59 \mathrm{~kg}$ for mature cows and 1.06 and $2.12 \mathrm{~kg}$ for first-calf heifers, before and after calving, respectively. Severe weather prevented feeding of supplements on 6 of the 88 days. Cows and calves were weighed after being gathered at daybreak and withheld from feed and water for approximately 6 hours. Calves were weighed shortly after birth. Condition loss of cows was estimated by scoring the cows for condition at the initiation and conclu- sion of the trial. Scores of 1 to 9 were used, with 1 being the thinnest and 9 the fattest.

Since the number of mature cows which calved previous to the trial was disproportionate among treatments, initial weight of cows that calved before the trial was adjusted to a pregnant weight basis. The regression equation used to correct initial cow weight was (Ewing et al., 1966 and unpublished data):

$$
\begin{gathered}
\text { Adjusted initial } \\
\text { weight }(\mathrm{kg})
\end{gathered}=\begin{aligned}
& \text { Actual initial weight }+ \\
& (\text { calf birth wt } \times 1.9697)- \\
& 19.0 .
\end{aligned}
$$

Calves out of mature cows were sired by Charolais bulls while calves out of first-calf heifers were sired by Hereford bulls. Weaning weights were adjusted to a 205-day, steer basis; adjusted 205-day weights of heifers were multiplied by 1.05. Dehydrated alfalfa pellets (alfalfa, aerial pt. dehy grnd, mn .17 protein (1) 1-00-023) were provided for calves in a creep during the latter part of the trial.

Data were analyzed by least squares regression analysis with the F-test used to test for significant treatment differences, and students' $t$-test for differences between any two treatments.

Trial 2. Trial 2 was conducted at the same location as trial 1 during the following winter. Cows were managed in the same manner, including the supplementation of cows in individual stalls. A total of 164 experimental cows consisted of 81 Herefords, 44 Angus and 39 Angus $x$ Holstein crossbreds. They calved either shortly before or after the trial started. Initial weights of cows that calved before the experiment started were adjusted to a pregnant basis as in trial 1 .

Supplements were formulated as in trial 1 but those containing MHA (6A and $7 \mathrm{~A}$ ) were replaced. In supplement $6 \mathrm{~B}$ the NPN fraction was a mixture of urea $(50 \%)$ and biuret $(50 \%)$ while in supplement $7 \mathrm{~B}$ urea, present in an extruded grain-urea mixture, contributed onehalf of the crude protein. Amounts of daily supplement offered per cow were 1.05 and 2.12 $\mathrm{kg}$ for Hereford and Angus cows and 1.59 and $2.65 \mathrm{~kg}$ for crossbred cows, before and after calving, respectively. The weather during trial 2 was more severe and prevented the feeding of supplements 22 days of the 112-day feeding trial. When supplements were not fed, prairie hay was fed daily. In addition, the $30 \%$ natural protein supplement was group-fed at the rate of 
$1.36 \mathrm{~kg}$ per head per day when the experimental supplements had not been fed for 3 consecutive days. Cows were weighed after overnight confinement in corrals without feed or water for 12 hours.

Statistical analysis of the data was conducted as in trial 1, except analysis of covariance was used to adjust the initial weight of the Hereford cows to an equal basis (Snedecor and Cochran, 1967). Since trial $\times$ treatment, breed of cow $x$ treatment and age of cow $x$ treatment interactions were not significant $(\mathrm{P}>.10)$, treatments $1,2,3,4,5,8$ and 9 were pooled for trials 1 and 2 , and the pooled data were analyzed in the same manner as in each individual trial.

Biuret Adaptation Trials. Nine mature steers, equipped with rumen cannulas, were used to measure the rate and extent of adaptation of rumen microorganisms to biuret under range conditions. The steers were allowed to graze in the same pasture as the cows during the first 74 days of trial 2 , and were fed and managed in the same manner as the cows. They were randomly allotted to supplemental treatments 2, 4 and 8 (table 1) and were individually fed $1.59 \mathrm{~kg}$ of the supplement per day. Rumen samples from each steer were obtained on days $0,4,6,17,20,28,34,49$ and 74 of the experiment. Biuretolytic activity of the rumen contents was determined by procedures described by Johnson and Clemens (1973).

These data were analyzed with analysis of variance with the $F$ test utilized to test significant differences. Differences between means were determined by the LSD method (Snedecor and Cochran, 1967).

Trial 3. A growth trial was conducted in drylot during a 93-day period during the summer to compare the apparent utilization of supplemental nitrogen from natural protein, urea and urea in an extruded grain-urea mixture (supplements 2, 5 and 10, table 1). A total of 27 yearling heifers (nine Hereford and 18 Hereford $\times$ Angus-Holstein) was blocked according to breed and weight and randomly assigned to three treatment groups of nine heifers each. Nine heifers (three from each treatment) were maintained in each of three lots. Tallgrass prairie forage was fed ad libitum. Hay (native plants, mid west, hay, s-c, mid-blm (1) 1-07-956) for the first phase (44 days) had been cut in mid-July and was of moderate quality. Hay (native plants, mid west, hay, s-c, over ripe (1) 1-03-188) for the second phase
(44 days) had been cut in early April and resembled late-winter dry range grass. Crude protein content of the two hays was $\mathbf{5 . 0}$ and $3.9 \%$, respectively. Supplements were fed in individual stalls twice daily at the rate of $454 \mathrm{~g}$ per feeding ( $908 \mathrm{~g} /$ day).

Heifers were weighed after a 14-hr shrink without feed or water. Change in condition was estimated in the same manner as in trials 1 and 2. Hay intake of each treatment group was measured for 5 days at the end of each phase of the experiment. During this time supplemental feeding continued as before, but each treatment group was maintained in a separate lot which allowed daily measurement of hay intake.

Analysis of variance was used to test for significance and the LSD multiple range test was used to test for significant differences between treatment means (Snedecor and Cochran, 1967).

\section{RESULTS AND DISCUSSION}

Treatments 6 and 7 were different in trials 1 and 2 and will be discussed within each trial; the results and discussion of treatments $1,2,3$, $4,5,8$ and 9 will be based on the pooled data of trials 1 and 2 .

Trial 1, Effects of MHA. The results of trial 1 are shown in table 2 . Cows receiving the negative control ( $15 \%$ natural protein) supplement lost more weight $(\mathrm{P} \approx .02)$ than cows consuming the positive control $(30 \%$ natural protein) indicating that protein was deficient in the negative control and providing validity for the experimental design for evaluating supplements.

Addition of MHA lowered palatability and consequently intake of supplements. Effects of MHA on palatability were probably more pronounced in this trial than in previous research (Chandler et al., 1970; Lofgreen, 1970; Polan et $a l ., 1970$ ) because of the high levels of NPN and the higher percentage of MHA in the concentrate portion. Lack of competition among individually fed cows may have contributed to low intake of supplements containing MHA and/or urea, since lactating cows grazing similar forage were group-fed the urea containing supplement with no intake problems (Rush and Totusek, 1973).

The effect of MHA in urea or biuret supplements on cow weight loss was small. Weight loss of cows receiving biuret, biuret + MHA, urea and urea + MHA was not different $(\mathrm{P}>.05)$; however, the cows consuming the supplement 


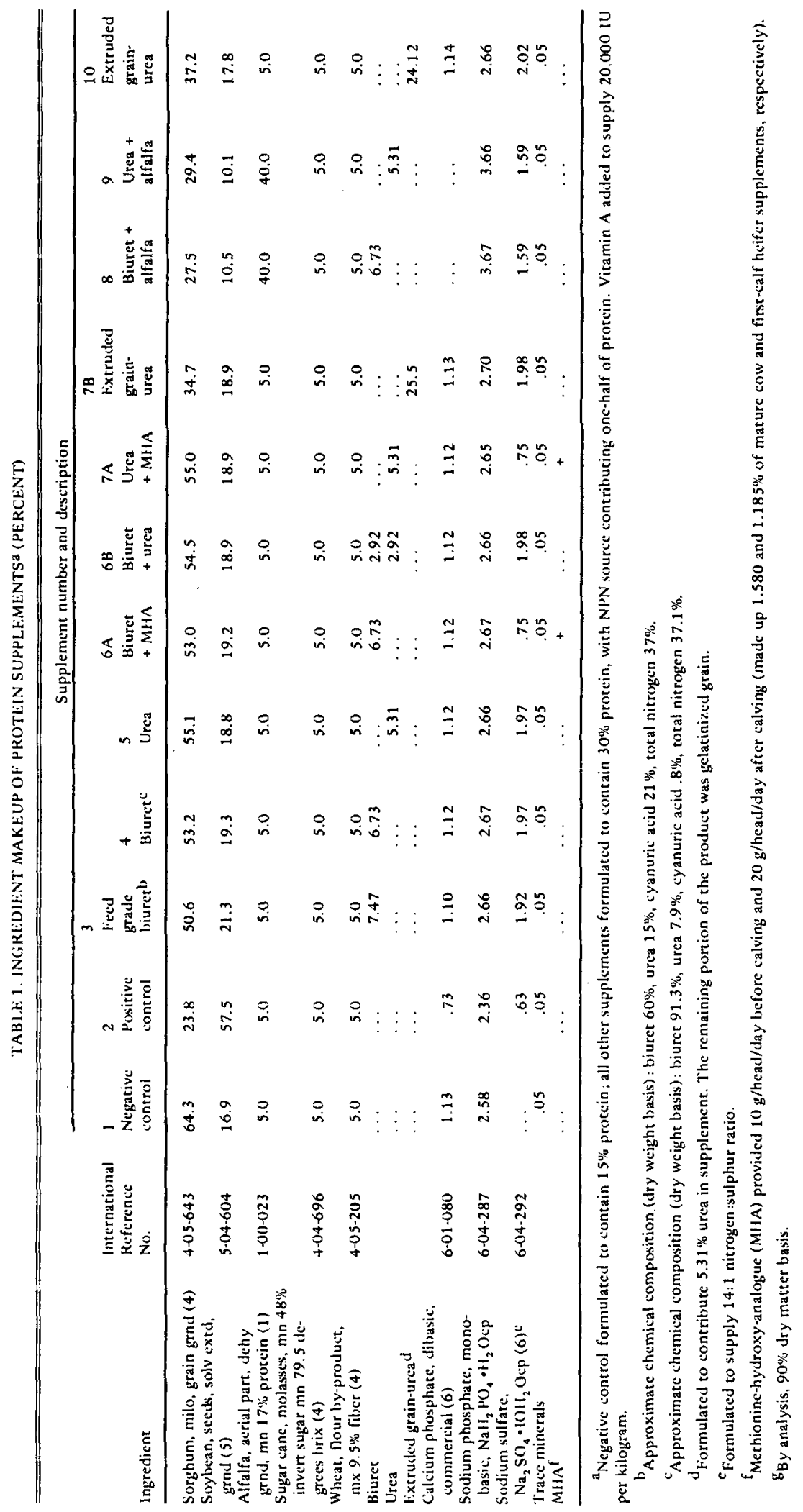




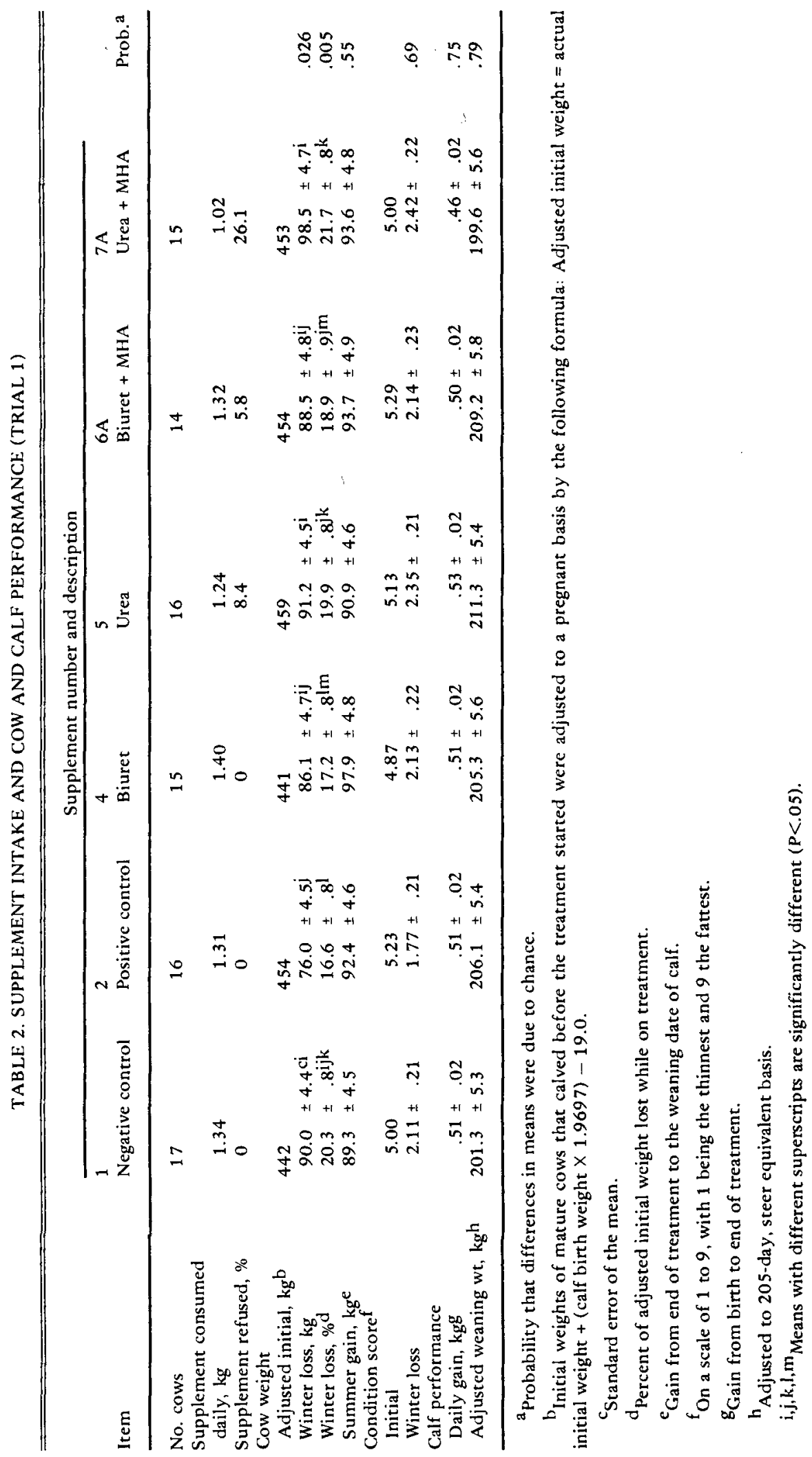




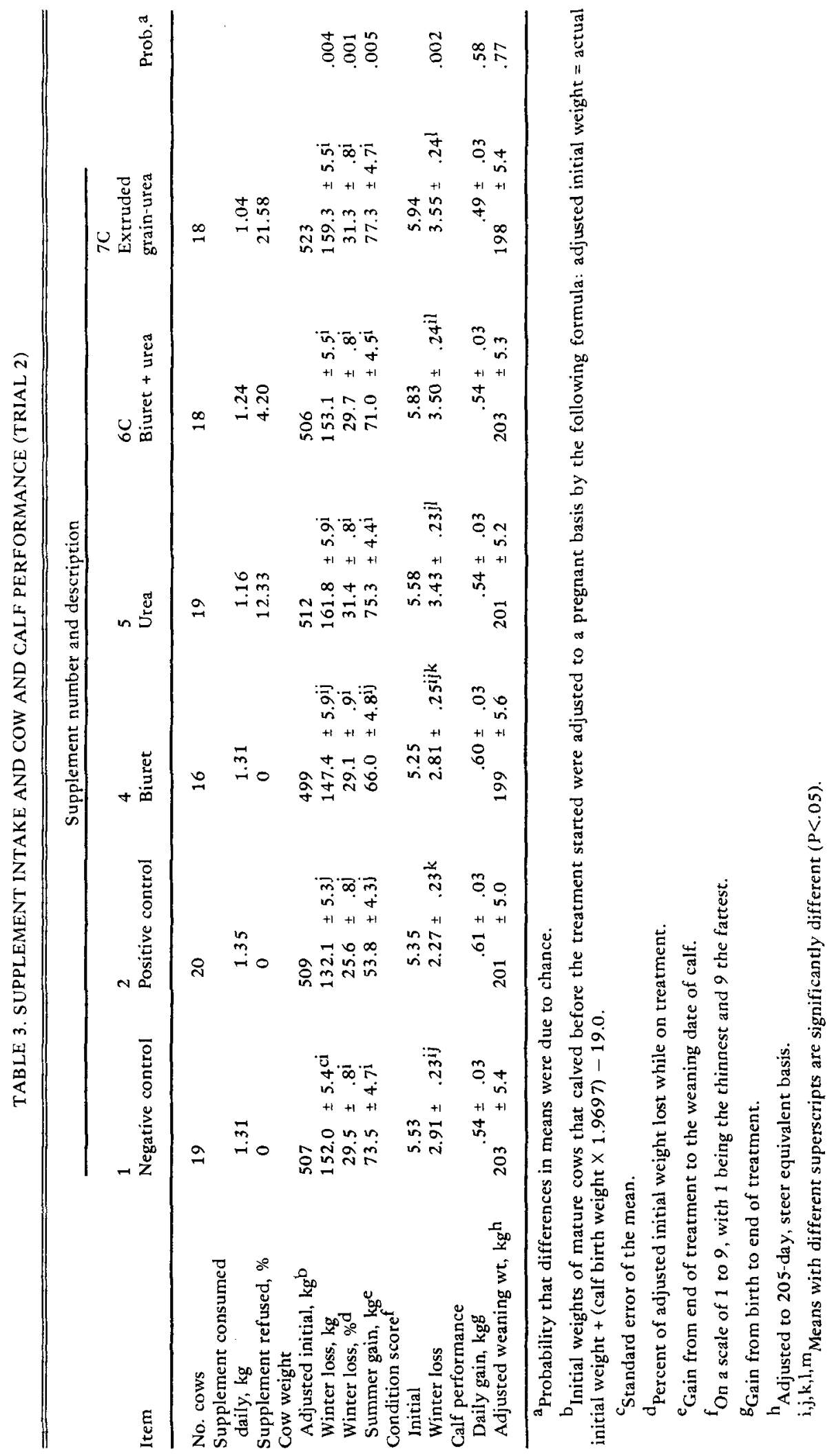




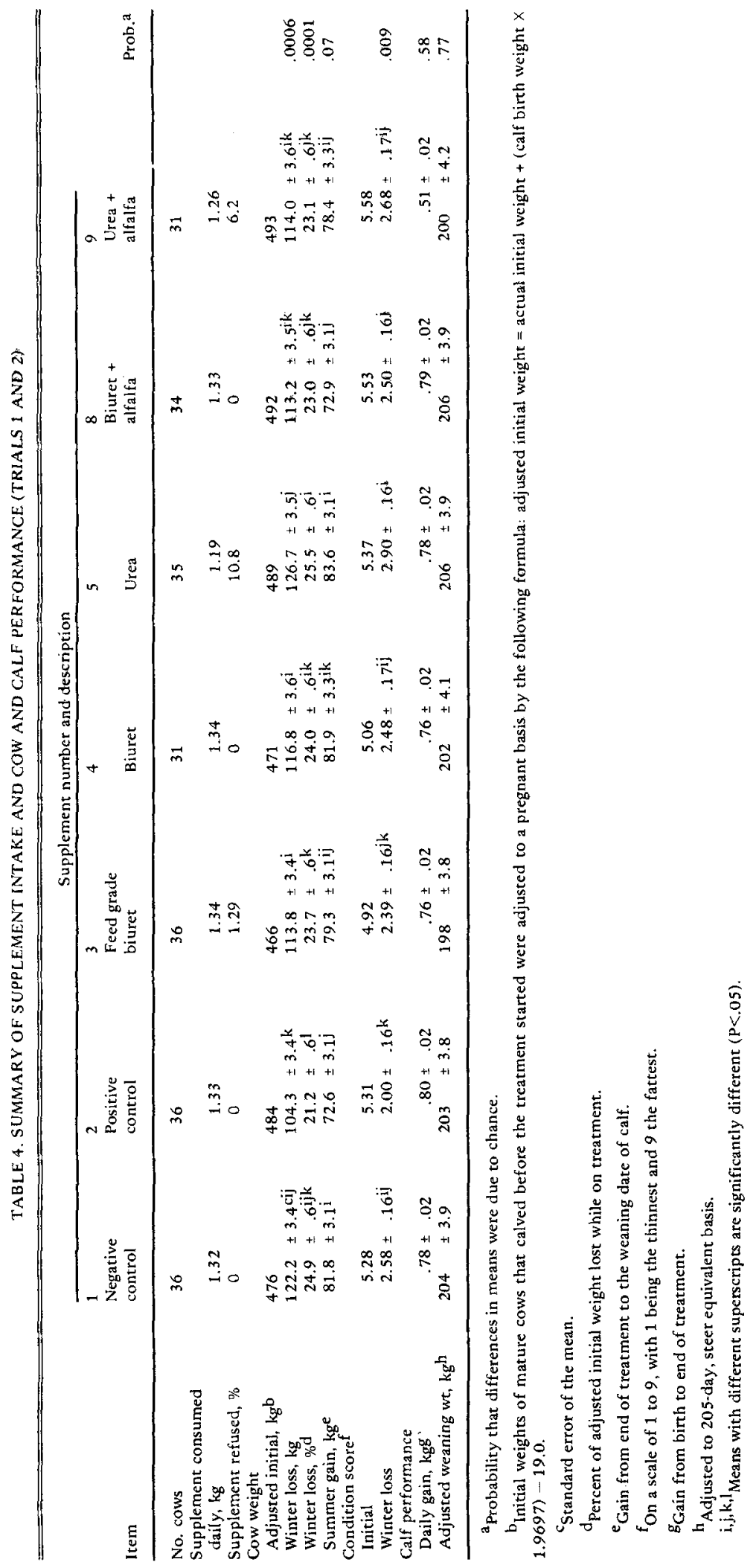


containing urea + MHA had the largest weight loss.

Analysis of covariance (Snedecor and Cochran, 1967) was used to correct cow weight loss means to differences in supplement intake. Adjusted weight losses (kilograms or percent) of cows receiving biuret, biuret + MHA and urea were not different $(P<.10)$, but they were greater $(\mathrm{P}<.05)$ than weight loss of cows receiving urea + MHA.

Treatment did not affect condition change of cows $(\mathrm{P} \approx .69)$ or summer cow gain $(\mathrm{P} \approx 55)$. Since treatment did not affect daily gain of calves from birth to end of treatment $(P \approx 75)$ and adjusted weaning weight $(\mathrm{P} \approx .79)$, milk production of cows was apparently not affected by MHA. This lack of lactation response to MHA is in contrast to results with beef cows (Varner et al., 1973) and dairy cows (Polan et al., 1970). These workers combined MHA with natural protein, but MHA significantly increased bacterial nitrogen and cellulose digestion, and lowered ammonia levels with urea in vitro (Gil et al., 1973).

Trial 2, Effects of Biuret + Urea and Extruded Grain-Urea. Supplements $6 \mathrm{~B}$ and 7B in trial 2 contained urea + biuret (equal nitrogen from each) and an extruded grain-urea mixture, respectively. The results of trial 2 are shown in table 3 . As in trial 1 cows on the negative control lost more $(\mathrm{P} \approx .01)$ winter weight than those on the positive control.

A combination of urea + biuret was almost as palatable as biuret alone $(4.2 \%$ of the supplement refused), but weight loss of cows receiving urea + biuret was not different $(P>.05)$ from that of cows receiving biuret or urea alone.

Weight losses of cows consuming extruded grain-urea and other NPN supplements were not different $(P>.05)$. The large weight loss of cows on extruded grain-urea was conceivably a reflection of low intake of the less palatable supplement. However, correcting weight loss means for supplement intake indicated little difference between urea and extruded grain-urea; utilization of urea was apparently low in both supplements and not improved by extruding with grain.

Treatment effects (urea, biuret, extruded grain-urea) on condition loss of the cows were similar to those observed for cow weight loss. Treatment did not affect daily gain of calves while on treatment $(\mathrm{P} \approx 58)$ or adjusted weaning weight $(\mathrm{P} \approx .77)$.

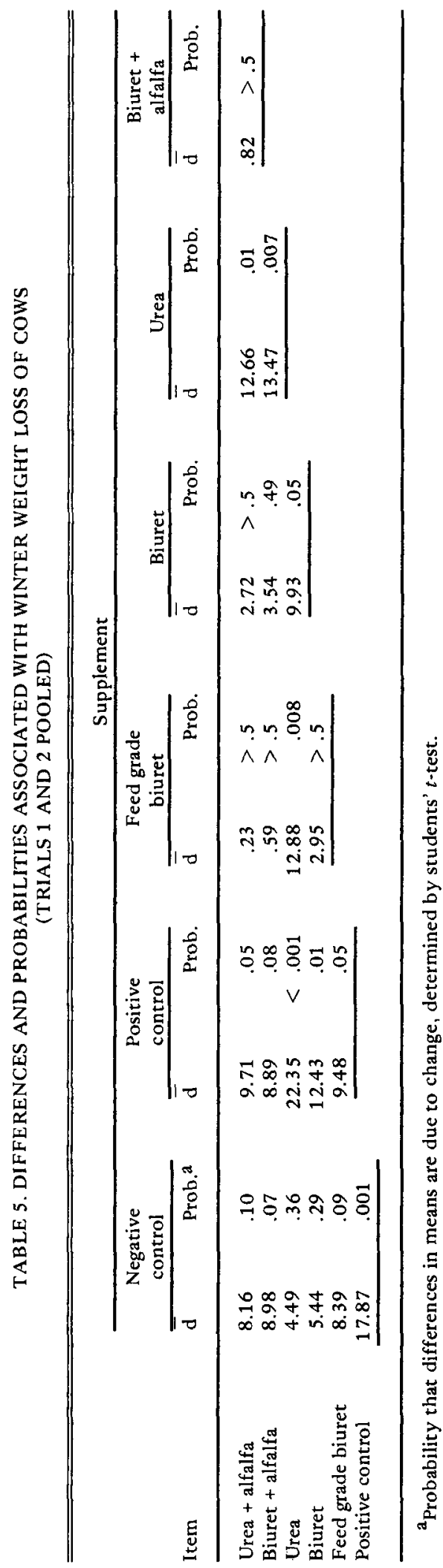


Trials 1 and 2 Pooled. Since a treatment $x$ trial interaction was not detected $(\mathrm{P}>.10)$, treatments common to trials 1 and 2 were pooled for analysis. Results of the pooled data are shown in tables 4 and 5. Cows fed the negative control supplement lost more winter weight $(P \approx .001)$ and more condition than those on the positive control. Weight and condition loss of cows fed NPN supplements were greater $(\mathrm{P}<.05)$ than for the cows fed the positive control.

Cows fed biuret lost fewer kilograms weight $(\mathrm{P} \approx 05)$, less percent weight $(\mathrm{P} \approx 07)$ and less condition $(\mathrm{P} \approx .06)$ than cows fed urea. Cows fed urea refused $10.8 \%$ of the supplement and consumed $.14 \mathrm{~kg}$ less than cows fed biuret. However, analysis of covariance (Snedecor and Cochran, 1967) showed the $b$ and $r$ values were approximately zero, so no adjustment for supplement intake was made.

The advantage for biuret may be due to slower hydrolysis with ammonia release at a rate more comparable to the rate of energy release from the mature forage. The greater apparent utilization of biuret is in agreement with Tollett et al. (1969) and Raleigh and Turner (1968) but in contrast to results of Clanton (1970), Turner and Raleigh (1969) and Turner et al. (1970).

Feed grade biuret was not different $(\mathrm{P}>.05)$ than biuret in any trait measured $(P>.50$ for cow winter weight loss). Apparently the combination of NPN sources in feed grade biuret (including $15 \%$ urea) was without affect.

The addition of $40 \%$ dehydrated alfalfa to the urea supplement was beneficial in terms of cow weight loss $(\mathrm{P} \approx .01)$, in agreement with Karr et al. (1965), Nelson et al. (1957) and Clanton (1970). Palatability also appeared to be improved slightly (6.2 vs $10.8 \%$ refusal). The biuret supplement was not benefited by $40 \%$ alfalfa in terms of cow weight loss $(\mathrm{P} \approx .49)$; weight loss on biuret and urea supplements with $40 \%$ alfalfa was comparable.

The NPN supplements did not affect calf daily gain while on treatment $(\mathrm{P} \approx .58)$ or adjusted weaning weight $(\mathrm{P} \approx .77)$.

Biuret Adaptation Trial. The biuretolytic activity observed in the rumen fluid of steers supplemented with the positive control, biuret and biuret + alfalfa $(40 \%)$ is shown in figure 1 . No appreciable activity was apparent on days 0 or 4 . By day 6 biuretolytic activity of biuret supplemented steers was greater $(P<.05)$ than that of natural protein steers. Adaptation was

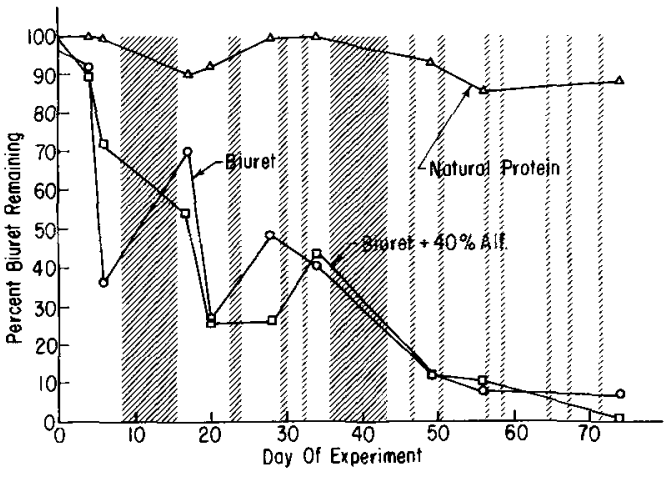

Figure 1. Biuretolytic activity of steers fed range supplements containing natural protein, biuret and biuret $+40 \%$ alfalfa. (Shaded areas indicate days biuret supplements were not fed).

not lost when biuret supplements were not fed for nine continuous days after day 7 ; rumen samples were taken on day 17,1 day after supplemental feeding was reinitiated. Biuretolytic activity increased to $88 \%$ on day 49 although the steers were only supplemented 4 of the preceding 14 days. The biuret steers continued well adapted on days 56 and 74 of the trial.

Steers supplemented with natural protein did not develop appreciable biuretolytic activity and degraded less biuret $(\mathrm{P}<01)$ than biuret fed steers from day 20 to the end of the trial. Biuretolytic activity of steers fed the two biuret supplements was not different $(P>.10)$ for any of the sampling days. This agrees with results of Gilchrist et al. (1968) and Johnson and Clemens (1973).

The rate of development of biuretolytic activity was faster than reported previously (Johnson and Clemens, 1973), or indicated by nitrogen balance (Hatfield et al., 1959; Oltjen et al., 1969; Tomlin et al. 1967). However, Clemens and Johnson (1973) and Wyatt (1973) recently found marked biuretolytic activity in 3 to 4 days in lambs fed high roughage diets. The low protein $(3 \% \mathrm{CP})$ of the major portion of the steers' diet (dry range grass) in this trial may have facilitated the short adaptation period (Schroder and Gilchrist, 1969).

Clemens and Johnson (1973), Johnson and Clemens (1973) and Schroder and Gilchrist (1969) found a rapid loss (4 days) of biuretolytic activity when biuret was removed from the diet. Biuretolytic activity was not lost on day 17 of this trial even though supplemental 
RUSH, JOHNSON AND TOTUSEK

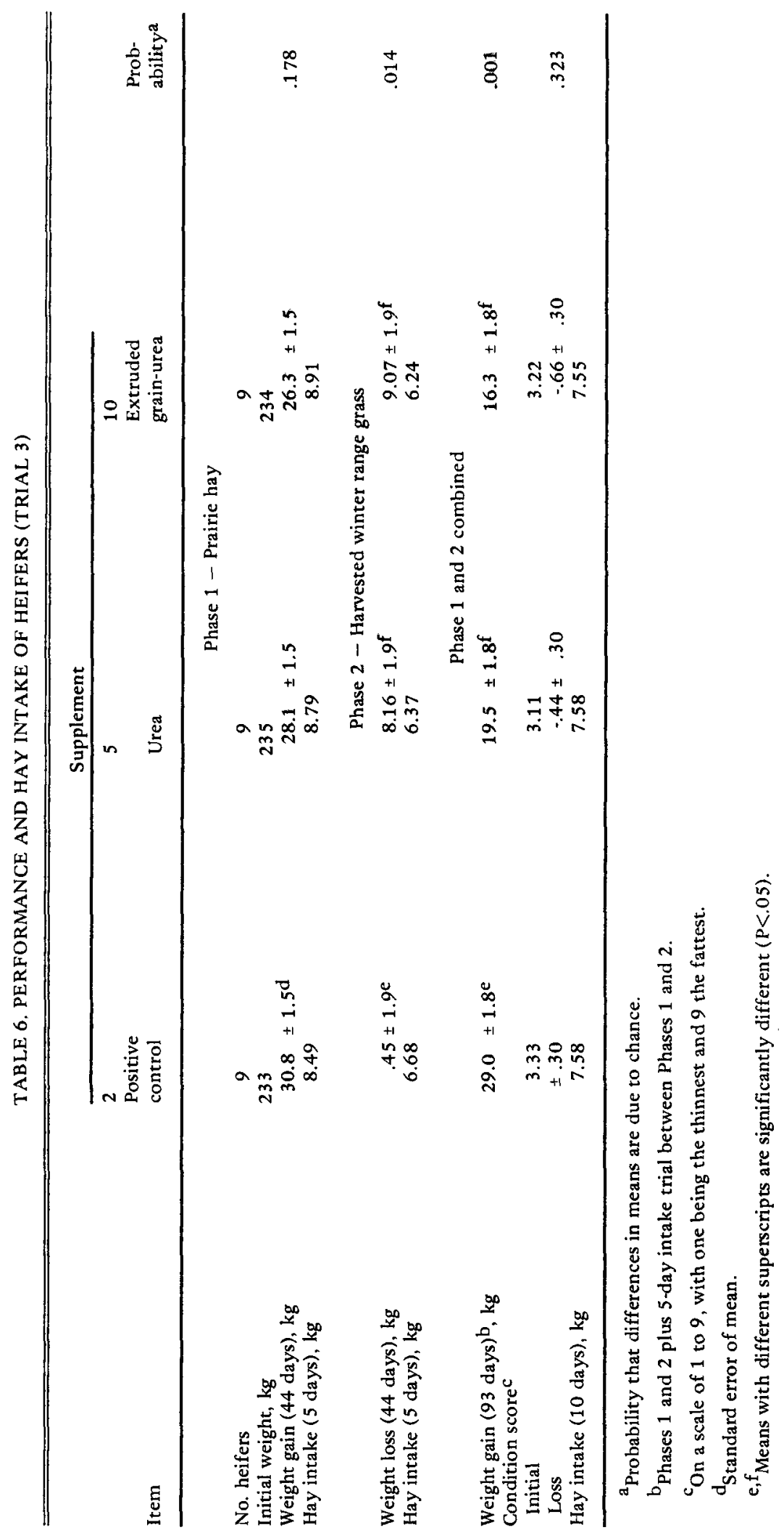


biuret was not fed 9 of the previous 10 days. Biuret was fed $24 \mathrm{hr}$ prior to sampling, a rather short time for development of biuretolytic activity if it were lost the previous 9 days. The high biuretolytic activity (88\%) on day 49 also was unexpected due to the previous intermittent and irregular feeding pattern.

These data indicate that either complete biuretolytic activity was not lost during the intermittent feeding period or the rumen microflora were able to readapt to biuret at a faster rate than reported by Schroder and Gilchrist (1969). Perhaps previously adapted animals "readapt" faster than animals never previously fed biuret (Clemens and Johnson, 1973). These data also provide support for the apparent utilization of some biuret by cows in trials 1 and 2.

Trial 3. Results of trial 3 are shown in table 6. Weight gain of heifers appeared to be only slightly affected $(P \approx 18)$ by nitrogen source when moderate quality hay was fed; calves that received the all natural protein supplement had the highest gain. There was a difference $(\mathrm{P} \approx .01)$ in treatments when harvested winter range grass was fed during the second phase of the experiment. Heifers consuming the natural $30 \%$ protein supplement lost less weight $(P \approx .05)$ than the heifers receiving the urea containing supplements.

A treatment $x$ phase interaction was not detected $(P>.10)$ so the two phases were pooled for statistical analysis; heifers fed the $30 \%$ natural supplement gained more $(\mathrm{P}<.01)$ than the heifers fed either urea supplement. Gains of heifers fed the two urea supplements were not different $(P>, 40)$. Heifers fed the natural protein supplement maintained their condition during the trial while the two urea groups lost in condition $(\mathrm{P} \approx .32)$. Hay intake was not affected by supplement $(P>.50)$ during either phase of the trial.

The extruding of grain with urea apparently failed to increase nitrogen utilization from urea as indicated by body weight and condition, in agreement with Clanton (1970) but in contrast with results of Tucker and Harbers (1972), Tucker et al. (1972), Helmer et al. (1970) and Owen and Applemen (1970).

\section{LITERATURE CITED}

Bloomfield, R. A,, G. B. Garner and M. E. Muhrer. 1960. Kinetics of urea metabolism in sheep. J. Anim. Sci. 19:1248, (Abstr.).
Clanton, D. C. 1970. Non-protein-nitrogen in range supplements. Proc. Texas Nutrition Conference, 25:131.

Clemens, E. T. and R. R. Johnson. 1973. Biuretolytic activity of rumen microorganisms as influenced by the frequency of feeding biuret supplement. J. Anim. Sci. 37:1027.

Chandler, P. T., C. E. Polan and D. P. Shaw. 1970. Methionine hydroxy analogue and lipid metabolism in the lactating cow. J. Dairy Sci. 53:376. (Abstr.).

Ewing, S. A., Larry Smithson, Dwight Stephens and Derald McNutt. 1966. Weight loss patterns of beef cows at calving: Okla. Agr. Exp. Sta. Misc. Pub. $78 ; 64$.

Gil, L, A., R. L. Shirley and J. E. Moore. 1973. Effect of methionine hydroxy analog on bacterial protein synthesis from urea and glucose, starch or cellulose by rumen microbes, in vitro. J. Anim. Sci. 37:159.

Gilchrist, F. M. C., E. Potgieter and J. B. N. Voss. 1968. The biuretolytic activity of ruminal flora of sheep fed practical rations containing biuret. $J$. Agr. Sci. 70:157.

Griel, L. C., Jr., R. A. Patton, R. D. McCarthy and P. T, Chandler. 1968. Milk production response to feeding methionine hydroxy analogue to lactating dairy cows. J. Dairy Sci. 51:1866.

Hatfield, E. E., U. S. Garrigus, R. M. Forbes, A. L. Neumann and W. Gaither. 1959. Biuret-a source of NPN for ruminants. J. Anim. Sci. 18:1208.

Helmer, L. G., E. E. Bartley and C. W. Deyoe. 1970. Feed processing VI. Comparison of starea, urea and soybean meal as protein sources for lactating dairy cows. J. Dairy Sci. 53:883.

Johnson, R. R. and E. T. Clemens. 1973. Adaptation of rumen microorganisms to biuret as a NPN supplement to low quality roughage ration for cattle and sheep. J. Nutr. 103:494.

Karr, M. R., U. S. Garrigus, E. E. Hatfield and H. W. Norton. 1965. Factors affecting the utilization of nitrogen from different sources by lambs. J. Anim. Sci. 24:459.

Lofgreen, G. P. 1970. Methionine hydroxy analogue and/or sulfur in rations containing urea. Calif. Feeders Day Rep.-1970. Davis, California.

Nelson, A. B., M. B. Greeley, I. A. Miller and G. R. Waller. 1957. Protein supplements for wintering beef cattle. J. Anim. Sci. 16:1085. (Abstr.).

Oltjen, R. R., E. E. Williams, Jr., L. L. Slyter and G. V. Richardson. 1969. Urea versus biuret in a roughage diet for steers. J. Anim. Sci. 29:816.

Owen, F. Y. and R. D. Applemen. 1970. Value of a gelatinized milo-urea mixture and DEHY-100 (pelleted preparation) as carriers of urea in lactation rations. Proc. XVIII Int. Dairy Congr. Sidney, Australia. 1E:540.

Polan, C. E., P. T. Chandler and C. M. Miller. 1970. Methionine hydroxy analog; varying levels for lactating cows. J. Dairy Sci. 53:607.

Raleigh, R. J. and H. A. Turner. 1968. Biuret and urea in range cattle supplements. Proc. West. Sec. Amer. Soc. Anim. Sci. 19:301.

Rush, Ivan and Robert Totusek, 1973. Frequency of feeding urea supplements. J. Anim. Sci. 37:355. (Abstr.).

Schroder, H. H. E. and F. M. C. Gilchrist. 1969. Adaptation of ovine ruminal flora to biuret. J. Agr. 
Sci. 72:1.

Snedecor, G. W. and W. G. Cochran. 1967. Statistical Methods (6th Ed.). Iowa State University Press, Ames.

Tollett, J. T., R. W. Swart, R. M. Ioset and J. A. Templeton. 1969. Biuret as a source of nitrogen for wintering steers. Proc. West. Sec. Amer. Soc. Anim. Sci. 20: 325.

Tomlin, D. C., L. E. Harris and J. E. Butcher. 1967. Biuret digestion in sheep. J. Anim. Sci. 26:931. (Abstr.).

Tucker, L. L. and L. H. Harbers. 1972. Starea, urea and soybean meal as a protein source in growing and finishing cattle rations. Kan. Agr. Exp. Sta. Bull. 557:43.

Tucker, L. L., L. H. Harbers and E. F. Smith. 1972. Starea, urea and soybean meal compared in winter- ing rations for cows on bluestem pasture II. Effect on birth and weaning weight of progeny and rebreeding performance. Kan. Agr. Exp. Sta. Bull. $557: 48$.

Turner, H. A. and R. J. Raleigh. 1969. Biuret and urea fro growing cattle. Proc. West. Sec. Amer. Soc. Anim. Sci. 20:331.

Turner, H. A., R. J. Raleigh and R. L. Phillips. 1970. Energy level and nitrogen source for fall calving cows. Proc. West. Sec. Amer. Soc. Anim. Sci. 21:75.

Varner, L. W., R. A. Bellows and R. R. Oltjen. 1973. Supplemental methionine hydroxy analog for beef cows. J. Anim. Sci. 37:358. (Abstr.).

Wyatt, Roger Daniel. 1973. Factors affecting biuret adaptation by rumen microorganisms in sheep. $M$. S. Thesis. Oklahoma State University, Stillwater. 